\title{
Дисперсии «умных» полимеров
}

\author{
(C) 2020 Кущев П.О. \\ Воронежский государственный университет, Воронеж
}

Поступила в редакцию 4.03.2020 г.

DOI: $10.17308 /$ sorpchrom.2020.20/2955

В статье осуществлен поиск поверхностно-активных веществ (ПАВ), как стабилизаторов дисперсий «умных» полимеров на основе N-винилкапролактама. Устойчивые во времени, способные реагировать на вариативные (повторяющиеся) изменения (давления, температуры, рН-среды, буферной ёмкости, напряжения, силы тока, поверхностного натяжения, конформации полимерных цепей, водородных и дисперсионных связей, стэкинг и свипинг-концентрирования, влагопоглощения) дисперсии получены гомополимеризацией $\mathrm{N}$-винилкапролактама и сополимеризацией его с 1винилимидазолом или $\mathrm{N}, \mathrm{N}$-диметиламиноэтилметакрилатом, с использованием высокомолекулярного стабилизатора полиакриламида, модифицированного моностеаратом сорбитана, а также сополимеризацией акриламида, акриловой кислоты и полисахаридов (крахмал, пектин, хитозан) и т.д.

Установлено, что устойчивые полимерные дисперсии N-винилкапролактама методами гетерофазной полимеризации получаются только при образовании новой фазы в виде полимерных адсорбционных слоев. Эти адсорбционные слои в ряде случаев образуют мицеллы и мицеллярные микрореакторы в результате супрамолекулярных процессов между функциональными группами мономера, амидными группами стабилизатора и полисахарида. Наличие супрамолекулярных процессов при сополимеризации основано на результатах просвечивающей электронной микроскопии, динамического светорассеяния и ИК-спектроскопии.

Показано, что гидродинамические радиусы частиц полимерной дисперсии поли-Nвинилкапролактама изменяются при нагревании в пределах указанных величин $\left[\left(\mathrm{R}_{\mathrm{h}} / \mathrm{R}_{\mathrm{h} \min }\right)=1.2-1.0\right]$, и частицы сохраняют термочувствительность, электрокинетическую и протолитическую чувствительность в течение нескольких месяцев.

Разработан способ синтеза агрегативно устойчивых дисперсий N-винилкапролактама и его сополимеров с 1-винилимидазолом или $\mathrm{N}, \mathrm{N}$-диметиламиноэтилметакрилатом с узким контролируемым распределением частиц по размерам. Синтез проводится в присутствии полиакриламида, модифицированного моностеаратом сорбитана (патент РФ №2569377-С1).

Приведены данные по методам литографии в синтезе «умных» полимеров, обеспечивающих постоянную степень контроля в процессе самосборки дисперсий. Методы усиленного электрополя, pН-контролируемого стэкинга, ион-селективного стэкинг-свипинга в капиллярном зонном электрофорезе эффективны для разделения катионов, анионов и нейтральных молекул с органической матрицей.

Ключевые слова: полимерная дисперсия, наногель, микрогель, стимул-чувствительность, сшивка.

\section{Введение}

Явления, происходящие в дисперсных системах полимерных материалов, в настоящее время привлекают все большее внимание исследователей. Вызвано это тем, что многие примеры оказались способны адекватным образом реагировать на незначительные изменения, происходящие во внешней среде. Подобный «отклик» на такие изменения среды как температура, давление, $\mathrm{pH}$, ионная сила раствора, освещенность, электрическое и магнитное поле, биополе, присутствие побочных веществ 
привело к появлению такого термина как «умные» полимеры. Результатом стимулчувствительных изменений в дисперсиях «умных» полимеров, называемых микрогелями, является набухание или контракция отдельных частиц геля, вариативность конформационных структур, образование новых фаз из гомогенной системы [1-29].

Установление новых физико-химических закономерностей в математике, физике, химии, биологии, медицине, минералогии привело к расширению перечня объектов, по отношению к которым стал привлекательным термин «умные». В связи с этим исследователи термин «умные» (по отношению к стимул-чувствительным объектам и явлениям) дополнили такими понятиями как нано-процессы и супрамолекулярные реакции [7-11, 15-20]. Эти понятия для микрогелей были своевременными и конструктивными, так как в дисперсиях стимул-чувствительность обусловлена наличием гидрофильных и гидрофобных фрагментов [22-31]. Полимеры подобной разновидности, представляющие одну из наиболее интенсивно развивающихся областей современной химии и технологии полимеров, используются в качестве эмульгаторов; дисперсантов; солюбилизаторов; полимерных пленок с молекулярными отпечатками для пьезосенсоров, хроматографических и сорбционных носителей [22-28, 31-41]. Необходимо подчеркнуть, что особое значение для решения указанных проблем было поставлено выдающимся советским химиком Антоном Владимировичем Думанским в 30-50 годах прошлого столетия. Основатель коллоидной химии в Советском союзе А.В. Думанский одним из первых в мире отмечал генетическую связь между коллоидной химией, химией полимеров, хроматографией, а также химией поверхностных явлений. [22-27]. Следует заметить, что впервые термин «микрогель» по отношению к полимерным дисперсиям был использован в работе Бейкера В.О. «Микрогель, новая макромолекула» в 1949 году, применительно к сшитым полибутадиеновым латексам. Этот термин Бейкер использовал применительно только к дисперсным системам редкосшитых полимеров, находящихся в коллоидном состоянии и которые закономерно относятся к наноструктурам. Частицы этих полимеров способны к набуханию в «хорошем» растворителе, а каждая частица представляет собой отдельную «гигантскую» макромолекулу, характеризующуюся постоянством состава. В современном представлении к наноструктурным системам относятся не только редкосшитые, но и сверхсшитые макропористые, макросетчатые, изопористые, микропористые сорбенты на основе полистирола и других полимерных матриц $[9,12,13]$. Наряду с наноструктурными фрагментами в таких сорбентах имеются и супрамолекулярные структуры, способные к способные к самоорганизации и существование которых не связано с возникновением новых химических связей [7-20]. В научных исследованиях закрепился еще один термин - «организованные среды», которые характеризуют дисперсии полимеров, а также оптически однородные растворы в твердых сорбентах, в которых в основной массе растворителя (водного или неводного) находятся наноразмерные системы, образующие собственную нанофазу. Следовательно, организованные среды гомогенны и однофазны в макромасштабе, но микрогетерогенны и двухфазны на наноуровне. Незначительное изменение $\mathrm{pH}$ среды или минимальное варьирование температуры, давления, биогенных добавок приводят многократно из гомогенного состояния в гетерогенное, а также к изменению в десятки раз степени набухания или сжатия микро- и макрогеля. Подобные системы уже нашли широкое применение в биологии, фармацевтике и медицине для своевременного мигрирования из микрогеля к живому органу ранее помещенных в полимер биологически-активных и лекарственных препаратов [5]. Модель такого мигрирования лекарства из полимерного микроконтейнера приведена на рис. 1. Кроме того, такие микро- и макрогели прошли корректные исследования и используются в пилотных проектах для синтеза пленок наноразмерной толщины в качестве чувстви-

Кущев П.О. / Сорбционные и хроматографические процессы. 2020. Т. 20. № 4. С. 493-515 
тельных слоев с молекулярными отпечатками в химических и биохимических сенсорах. Эти полимеры внедрены в технологию Ленгмюра-Блождет, осуществляющей перенос мономолекулярных слоев амфифильных органических молекул с поверхности жидкой субфазы на твердую поверхность подложки [17-30]. Макросетчатые и изопористые сверхсшитые полимеры служат в качестве сорбентов в хроматографических анализах, выделениях и разделениях биологически активных добавок, а также токсикантов из крови при гемодиализе [31-37, 41].

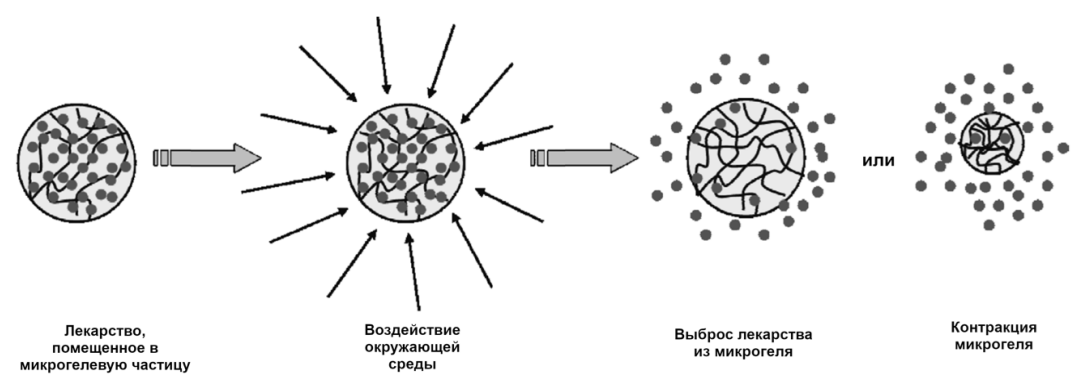

Рис. 1. Модель выделения лекарства из полимерной частицы под воздействием факторов среды

Fig. 1. A model of the extraction of drug from a polymer particle under the influence of the medium

Таким образом, полимерные дисперсии испытывают влияние связей на устойчивость микрогелей внутри самих коллоидов. Перечень факторов, влияющих на устойчивость вышеупомянутых связей довольно объемен: плотность вещества, мольная рефракция, мольный объем, число долей $-\mathrm{CH}_{2}-$ и $-\mathrm{CH}_{3}$ - групп в микрогелях, поверхностное натяжение (парахор), вязкость (реохор), текучесть (ортохор). Наряду с этим, устойчивость полимерных дисперсий зависит от внешних факторов: температуры, давления, теплопроводности, электропроводности, диффузионных параметров, УФ- и ИК-облучения, радиоактивности, влагосодержания в атмосфере. В связи с этим оптимизация способов получения и условий стабильности полимерных дисперсий вызывает необходимость учитывать как внутренние, так и внешние параметры [35-44].

Наиболее используемыми способами синтеза микрогелей являются эмульсионная полимеризация и литография $[4,47,48]$. В данном обзоре не ставится задача охватить все особенности получения дисперсий «умных» полимеров и рассмотреть варианты их детектирования. Главной целью этой публикации является ознакомление исследователей с эмульсионными и литографическими способами синтеза в микро- и наноэмульсиях на основе структурных особенностей функциональных групп в мономерах и инициаторах реакций.

\section{Классификация и способы получения «умных полимеров»}

Классификация микрогелей. Особое значение и в теоретическом, и в прикладном плане в настоящее время представляют исследования структуры и других физико-химических свойств водорастворимых (smart) полимеров. Стимулчувствительные гидрофильные полимеры обладают такими уникальными свойствами, как термочувствительность, светочувствительность, электрочувствительность, амфифильность макромолекулярной структуры жидких сред и фазовых превращений.

Амфифильность (дифильность) полимеров и сополимеров благодаря наличию в их структуре гидрофильных и гидрофобных групп обеспечивает стимул- 
чувствительность. При этом «отклик» на производимое воздействие над дифильной системой (температуры, освещенности, электричества, механохимического воздействия, биополярности, $\mathrm{pH}$, ионной силы) во многих случаях наблюдется «визуально» («взрывное» набухание или контракция гидрогеля, образование новой фазы из гомогенной системы (табл. 1).

Таблица 1. Характеристики растворов мицелл $[8,10,42]$

Table 1. Characteristics of micelle solutions

\begin{tabular}{|c|c|c|c|c|c|c|}
\hline $\begin{array}{c}\text { Форма } \\
\text { агрега- } \\
\text { тов } \\
\text { ПАВ }\end{array}$ & 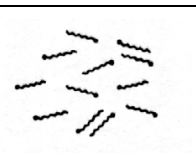 & 澲 潘 & & & 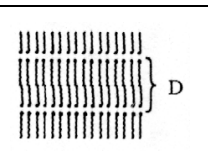 & 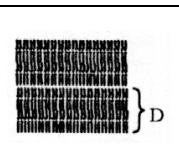 \\
\hline $\begin{array}{c}\omega\left(\mathrm{H}_{2} \mathrm{O}\right), \\
\%\end{array}$ & $>99.9$ & $30-99.9$ & $34-80$ & $23-40$ & $5-22$ & 0 \\
\hline $\begin{array}{c}\text { Состоя- } \\
\text { ние }\end{array}$ & $\begin{array}{c}\text { Раствор } \\
\text { (ниже ККМ) }\end{array}$ & $\begin{array}{c}\text { Мицелляр- } \\
\text { ный раствор }\end{array}$ & $\begin{array}{l}\text { Жидкокрис- } \\
\text { таллическое, } \\
\text { гексагональ- } \\
\text { ное плотно- } \\
\text { упакованное }\end{array}$ & $\begin{array}{c}\text { Жидко- } \\
\text { кристалли- } \\
\text { ческое, куби- } \\
\text { ческое (гра- } \\
\text { нецентри- } \\
\text { ческое) }\end{array}$ & $\begin{array}{c}\text { Жидко- } \\
\text { кристалли- } \\
\text { ческое, ла- } \\
\text { меллярное }\end{array}$ & $\begin{array}{c}\text { Кристалли- } \\
\text { ческое }\end{array}$ \\
\hline $\begin{array}{c}\text { Внеш- } \\
\text { ний вид }\end{array}$ & $\begin{array}{c}\text { Прозрач- } \\
\text { ный }\end{array}$ & $\begin{array}{c}\text { Прозрачный, } \\
\text { жидкий }\end{array}$ & $\begin{array}{c}\text { Прозрачный, } \\
\text { вязкий }\end{array}$ & $\begin{array}{c}\text { Прозрачный, } \\
\text { очень вязкий, } \\
\text { хрупкий }\end{array}$ & $\begin{array}{c}\text { Прозрачный, } \\
\text { умеренно } \\
\text { вязкий } \\
\end{array}$ & $\begin{array}{c}\text { Непрозрач- } \\
\text { ный твер- } \\
\text { дый } \\
\end{array}$ \\
\hline
\end{tabular}

Такие эффекты позволяют исследователям осуществлять вариативность в химических и биохимических системах. Температурное изменение на несколько градусов, увеличение поверхностного натяжения, вязкости, текучести, небольшого изменения $\mathrm{pH}$, ионной силы позволяет многократно и обратимо переходить от гомогенной системы к гетерогенной, менять на порядки степень набухания, выделять биологически активные вещества из смесей безреагентными методами, проводить иммобилизацию ферментов [8-10, 18-21].

Классификация основана на сопоставлении связей, возникающих в структуре «умных» полимеров. Различают физически сшитые гели (псевдогели), которые формируются за счет ориентационного, индукционного, дисперсионного, стекингэффектов, водородных связей. Асимметричность такой ассоциации и образование связей между противоположно заряженными полимерными цепочками, ведет к быстрому формированию (в минутном интервале) микро- и наногеля. При этом возможна и самосборка полимерных цепей, приводящая к агрегации и образованию физических гелей [31, 33, 35-37, 42].

Посредством супрамолекулярной самосборки дифильных блок- (или привитых) сополимеров в водных растворах формируются наногели. Их морфологической структурой является «ядро-оболочка», где гидрофобный сегмент блока в форме ядра окружен гидрофильной полимерной «короной», стабилизирующей мицеллу (рис. 2 , а) $[10,11,41,42,46]$. Наряду с мицеллярными наногелями выделяется группа гибридных наногелей [35-38, 43], композиты частиц, которые диспергированы в органических или неорганических матрицах. В качестве примера можно привести холестерин-несущий пуллулан, состоящий из пуллуланового остова и холестериновых «Хвостов». Агрегация с образованием монодисперсных наногелей предусматривает физические связи и ассоциацию между гидрофобными группами $[15,22-29,49]$.

Химически сшитые гели состоят из сетки, сшитой ковалентными связями [24$27,30]$. Подобные гели способны образовывать прочные связи во всей сетке геля. 
К химически сшитым гелям можно отнести ковалентно связанные (иммобилизованные) ферменты с функциональными группами ионообменников $[9,13,15,27,50]$.

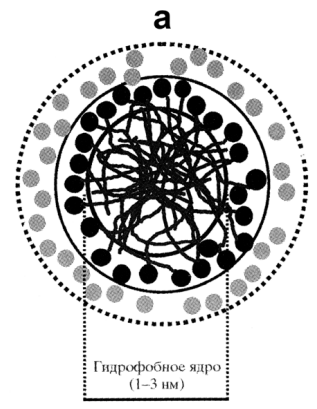

б

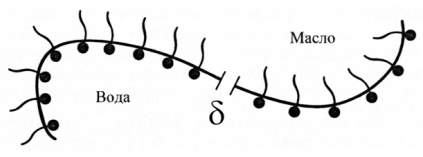

Рис. 2. Схема строения сферической мицеллы поверхностно-активного вещества (ПАВ) в воде (а) и пленка ПАВ биконтинуальной («седлообразной» геометрии с двумя главными радиусами кривизны противоположных знаков: Черные точки гидрофильные участки молекул ПАВ; белые точки - координированные молекулы воды; $\delta$ - точка «минимальной» поверхности, где средняя кривизна равна нулю.

Fig. 2. A model of a spherical micelle of the surface-active material (SAM) in water (a), and the SAM film of a bicontinuous geometry with two main radii of curvature being opposite: Black dots - hydrophilic regions of SAM particles; white dots - coordinated water molecules; $\delta$ - the point of minimal surface where the mean curvature equals zero.

Существует еще одна классификация микрогелей, основанная на их способности реагировать на внешние воздействия. Если гели не реагируют на внешние факторы, то они просто набухают в результате поглощения растворителя. В случае стимул-чувствительных гелей набухание и контракция происходят под действием температуры, давления, магнитного и электрического полей, кислотности и ионной силы раствора $[17,19,20,29]$.

Эмульсионная полимеризация микрогелей. Полимеризация микрогелей в эмульсии проводится путем ковалентного связывания. Наиболее важным в подобных реакциях является их локализация в ограниченном объеме, в связи с его влиянием на размер частиц микрогеля. Такие ограниченные объемы (пространства), именуемые микро- и нанореакторами, получают в эмульсиях масло-вода (прямая) или вода-масло (обратная) (рис. 2 а-б) [8, 10, 11, 29, 42, 47]. В работе [52] приведены данные по синтезу наногелей из поли-N-винилкапролактама (ПВК) и смеси толуола, гексадекана, азодиизобутиронитрила (АИБН), додецилсульфата натрия (ДДС) в воде. Полимеризация осуществлялась при $72^{\circ} \mathrm{C}$, перемешивании 500 об/мин в течение 17 часов.

Сополимеризацией $\mathrm{N}$-изопропилакриламида (ИПААм), $\beta$-циклодекстрина, акриловой кислоты и сшивающего агента N,N'-бисакриолцистамина синтезирован термочувствительный микрогель для таргетной доставки доксорубицина [53].

На кафедре высокомолекулярных соединений и коллоидной химии Воронежского государственного университета осуществлена гетерофазная сополимеризация $\mathrm{N}$-винилкапролактама (ВК) с N,N'-метилен-бис-акриламидом (МБААм) в присутствии гидрофобно модифицированного полиариламида (ГМПААм) [24-27].
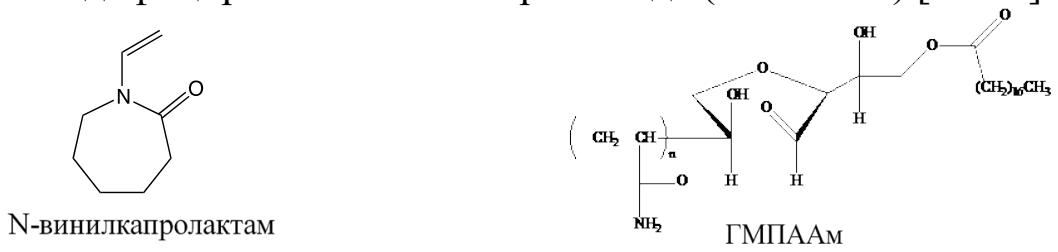
Для получения стабильных дисперсий ПВК используется полиакриламид, модифицированный моностеаратом сорбитана, функциональные группы которого образуют ассоциаты с группами мономера.

Мицеллообразование - очень важное свойство ПАВ, которое во много определяет их свойства и свойства ПАВ-содержащих растворов. Поэтому одним из этапов исследования является установление влияния поверхностного, межфазного натяжения и агрегации молекул ГМПААм в водных растворах и толуоле, основанный на прямом измерении силы отрыва кольца от границы раздела фаз.

На рис. 3 приведены изотермы поверхностного натяжения ГМПААм разных молекулярных масс, а в табл. 2 - данные по усилию отрыва кольца $(f)$ от межфазной границы. В первую группу образцов входят растворы полимера с молекулярной массой ГМПААм $0.3 \cdot 10^{6}-0.5 \cdot 10^{6}$; во вторую группу с $1.0 \cdot 10^{6}-1.6 \cdot 10^{6}$. Для первой группы (кривые 1 и 2 на рис.3) величины поверхностного натяжения оказались равны 61.4 и 63.7 кДж/м ${ }^{2}$ соответственно. Для второй группы ГМПААм поверхностное натяжение возможно установить только до концентрации их, равной $0.002 \mathrm{MM} / \mathrm{m}^{3}$ (кривые 3 и 4 на рис. 3). Более высокие концентрации ГМПААм способствуют формированию на границе вода-воздух прочных пленок двумерной структуры толщиной в несколько нм, стабилизирующих образующуюся новую дисперсную систему. Это препятствует точному определению поверхностного натяжения, из-за высокой молекулярной массы и наличия в составе комплексообразующих функциональных групп. Такой полимер выполняет функцию стабилизатора эмульсии полярного мономера ВК в воде и образующихся частиц дисперсий его полимера ПВК.

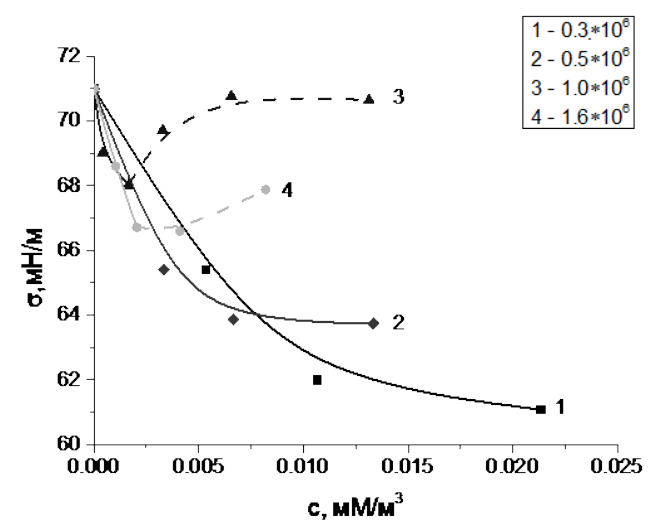

Рис. 3. Изотермы поверхностного натяжения водных растворов ГМПААм

Fig. 3. Isotherms of the surface tension of aqueous solutions of the hydrophobically modified polyacrylamide (HMPAAm).

Таблица 2. Значения усилия отрыва кольца от межфазной границы «водный раствор ГМПААм/толуол» при соотношении толуол-вода (об.) 1:1

Table 2. The force pulling the ring from the interphase boundary HMPAAm aqueous solution-toluene, when the ratio of toluene and water is $1: 1$

\begin{tabular}{|c|c|c|c|}
\hline № & $\mathrm{M}_{\mathrm{w}} \cdot 10^{6}$ & $\mathrm{f}_{\text {тол/вода, }} \mathrm{MH} / \mathrm{M}\left(\mathrm{c}=0.05 \Gamma /\right.$ дм $\left.^{3}\right)$ & $\mathrm{f}_{\text {тол/вода, }} \mathrm{MH} / \mathrm{M}\left(\mathrm{c}=0.10 \Gamma /\right.$ дм $\left.^{3}\right)$ \\
\hline 1 & 0.3 & 33.8 & 35.0 \\
\hline 2 & 0.5 & 36.3 & 35.9 \\
\hline 3 & 1.0 & 35.8 & 36.6 \\
\hline 4 & 1.6 & 40.6 & 38.3 \\
\hline
\end{tabular}

Устойчивость образующихся межфазных слоев зависит от количества добавленного мономера ВК и полимера ПВК [10-12, 42]. Проведенные исследования 
с 0.05 г/дм ${ }^{3}$ ГМПААм (молекулярной массы $0.3 \cdot 10^{6}$ ) показали, что в присутствии мономера ВК, величина межфазного натяжения значительно снижается с ростом его концентрации (рис. 4). Добавление в системы ПВК $\left(\mathrm{M}_{\eta}=27000\right)$, также ведет к снижению межфазного натяжения. Из представленных данных следует, что при добавлении ВК и ПВК устойчивость прямых эмульсий «вода-толуол» существенно возрастает. О стабилизации межфазного слоя после взаимодействия молекул ВК, ПВК с молекулами ГМПААм свидетельствуют также данные ИК-спектроскопии.

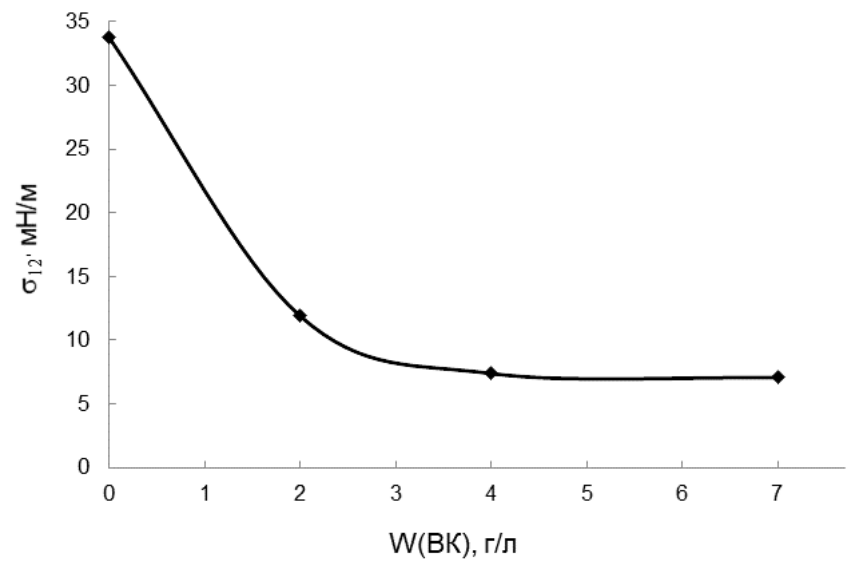

Рис. 4. Изотерма межфазного натяжения на границе раздела 0.05 г/дм ${ }^{3}$ раствор ГМПААм-толуол в зависимости от содержания мономера в системе

Fig. 4. Isotherm of the interfacial tension on the boundary of the $0.05 \mathrm{~g} / 1$ HMPAAmtoluene solution depending on the concentration of the monomer in the solution.

До взаимодействия с ГМПААм в ИК-спектре ВК отсутствуют полосы поглощения в области 3500-3270 $\mathrm{cm}^{-1}$ (рис. 5, табл. 3), характеризующие валентные коле-

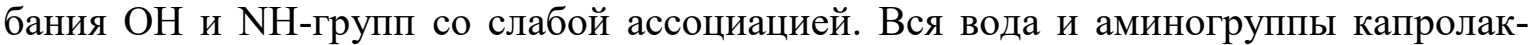
тамного цикла образуют прочные водородные связи (межмолекулярные) между собой, что проявляется в виде $v\left(\mathrm{OH} \times \times \times \mathrm{N}^{+} \mathrm{H}\right)\left(3160 \quad \mathrm{~cm}^{-1}\right)$, деформационных $\delta_{\text {as }}(\mathrm{OH} \times \times \times \mathrm{O})$ и $\delta_{\mathrm{s}}(\mathrm{OH} \times \times \times \mathrm{O})\left(1641\right.$ и $\left.1542 \mathrm{~cm}^{-1}\right)$ колебаний. Указанные максимумы характерны также резонансам Ферми (3161 и $\left.2980 \mathrm{~cm}^{-1}\right)$, Амиду I $\left(1644 \mathrm{~cm}^{-1}\right)$ и Амиду II $\left(1545 \mathrm{~cm}^{-1}\right)$. После взаимодействия ВК и ГМПААм в спектрах четко фиксируются максимумы, указанные выше, а также полосы поглощения веерных $\gamma_{w}\left(\mathrm{CH}_{2}\right)$, маятниковых $\gamma_{t}\left(\mathrm{CH}_{2}\right)$, торсионных $\gamma_{r}\left(\mathrm{CH}_{2}\right)$ колебаний $\left(1321,1266,980,730\right.$ и $\left.623 \mathrm{~cm}^{-1}\right)$ в Амид III, Амид IV, Амид VI соответственно. Следовательно, между ВК и ГМПААм происходит ассоциация путем образования водородных связей между полярными группами (гидрофильное взаимодействие) и между $\mathrm{CH}_{2}$-группами виниловых структур.

Особый интерес представляет взаимодействие с образованием водородных связей с участием метильных и метиленовых групп [29, 30, 49], в основе которых проявляется возможность синтеза 5-ти и 6-ти членных циклов $\left(1310,1080,624534 \mathrm{~cm}^{-1}\right)$. Финальной частью процесса взаимодействия ВК и ГМПААм можно считать гидрофобизацию поверхности мицеллярных микрореакторов, их укрупнение и стабилизацию.

В наибольшей степени в медицине, фармации, биотехнологии синтетики заинтересованы в получении полимерных мицеллярных микросфер с узким распределением частиц. 


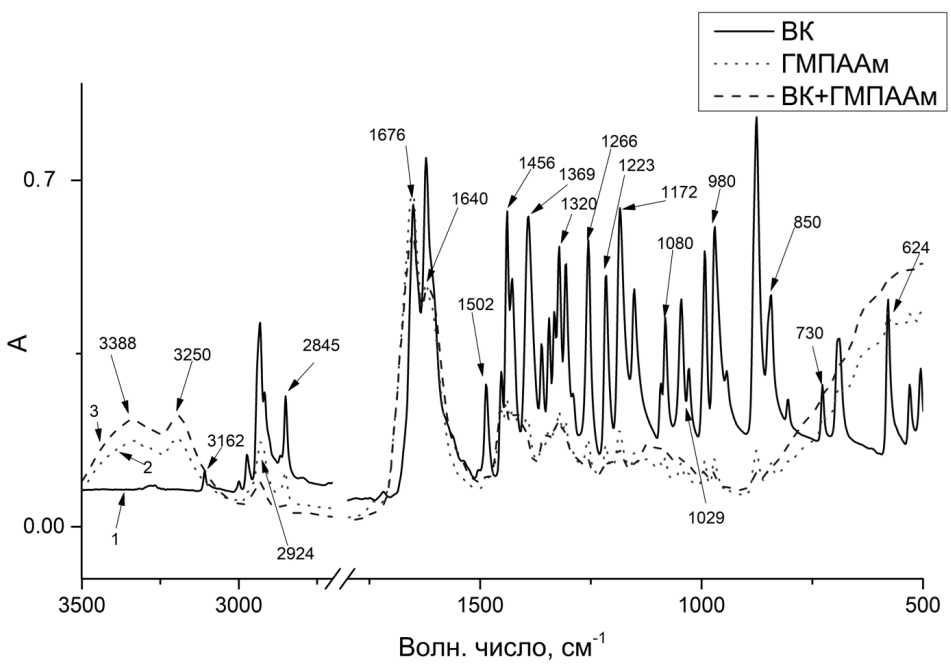

Рис. 5. ИК-спектры N-винилкапролактама (ВК) (сплошная линия 1),

ГМПААм (точечная линия 2) и их смеси (пунктирная линия 3)

Fig. 5. IR spectra of N-vinylcaprolactam (VCL) (curve 1), HMPAAm (dotted line 2), and their mixture (dash line 3)

Таблица 3. Отнесение полос поглощения в ИК-спектрах N-винилкапролактама (ВК), гидрофобномодифицированного полиакриламида (ГМПААм), персульфата калия (ПСК) и их смесей

Table 3. Assignment of the absorption bands in the IR spectra of $\mathrm{N}$-vinylcaprolactam (VCL), hydrophobically modified polyacrylamide (HMPAAm), potassium persulfate (PPS), and their mixtures

\begin{tabular}{|c|c|c|c|c|c|c|}
\hline \multirow{2}{*}{$\begin{array}{c}\text { Волн. } \\
\text { число, v, } \\
\text { см }^{-1}\end{array}$} & \multicolumn{5}{|c|}{ Вещество } & \multirow[b]{2}{*}{ Отнесение полос } \\
\hline & BK & ГМПААм & ПСК & $\begin{array}{c}\text { ВК+ } \\
\text { ГМПААм }\end{array}$ & $\begin{array}{l}\text { ВК+ПСК }+ \\
\text { ГМПААм }\end{array}$ & \\
\hline 1 & 2 & 3 & 4 & 5 & 6 & 7 \\
\hline 3388 & - & 3388 & - & 3382 & 3382 & $\begin{array}{c}\mathrm{NH} \times \times \times \mathrm{NH} \text { ассоциатах; } \\
\mathrm{OH} \text { воды с неассоц. } \\
\text { связями }\end{array}$ \\
\hline 3250 & - & 3250 & - & 3253 & 3248 & $\begin{array}{c}v(\mathrm{OH} \times \times \times \mathrm{NH}) \text { и } \\
v(\mathrm{OH} \times \times \times \mathrm{O}) \text { ассоц. связи }\end{array}$ \\
\hline 3162 & 3161 & 3162 & - & 3160 & 3158 & $\begin{array}{c}\mathrm{v}\left(\mathrm{OH} \times \times \times \mathrm{N}^{+}\right) \text {c BK }+\mathrm{H}_{2} \mathrm{O} ; \\
\text { резонанс Ферми (Амид I) } \\
+ \text { (Амид II) c NH }\end{array}$ \\
\hline 2980 & 2980 & 2980 & - & 2976 & 2976 & $\begin{array}{c}\text { Резонанс Ферми 2хАмид } \\
\text { II c NH; } v\left(\mathrm{CH}_{2}\right) \text { в } \mathrm{CH}_{2-} \\
\mathrm{R}=\mathrm{CHR}^{\prime}\end{array}$ \\
\hline 2845 & 2849 & 2853 & - & 2845 & 2845 & $v_{\mathrm{s}}\left(\mathrm{CH}_{2}\right)$ \\
\hline 1641 & 1644 & 1643 & - & 1641 & 1641 & Амид I $(\mathrm{C}=\mathrm{O}) ; \delta_{\mathrm{as}}\left(\mathrm{H}_{2} \mathrm{O}\right)$ \\
\hline 1545 & 1555 & 1559 & - & 1502 & 1502 & $\begin{array}{c}\text { Амид II } \delta(\mathrm{NH}+\mathrm{C}-\mathrm{N}) ; \\
\delta_{\mathrm{s}}\left(\mathrm{H}_{2} \mathrm{O}\right)\end{array}$ \\
\hline 1420 & 1423 & 1426 & - & 1419 & 1420 & $\begin{array}{c}\delta\left(\mathrm{CH}_{2}\right) \text { плоские; } \mathrm{N} \text { и } \mathrm{CO} \\
\text { вициальные; } \\
\delta_{\text {as }}\left(\mathrm{H}_{2} \mathrm{O} \times \times \times \mathrm{H}_{2} \mathrm{O}\right)\end{array}$ \\
\hline
\end{tabular}




\begin{tabular}{|c|c|c|c|c|c|c|}
\hline 1 & 2 & 3 & 4 & 5 & 6 & 7 \\
\hline 1369 & 1369 & 1372 & - & 1369 & 1367 & $\gamma_{w}\left(\mathrm{CH}_{2}\right) ; \delta_{\mathrm{s}}\left(\mathrm{H}_{2} \mathrm{O} \times \times \times \mathrm{H}_{2} \mathrm{O}\right)$ \\
\hline 1310 & 1320 & 1324 & - & 1321 & 1324 & $\begin{array}{c}\delta \text { плоские; } \gamma_{w}\left(\mathrm{CH}_{2}\right) ; \\
\gamma_{t} \text { взаимод. с Амид III; } \\
\text { СН в циклах }\end{array}$ \\
\hline 1266 & 1258 & 1256 & 1261 & 1268 & 1266 & $\begin{array}{c}\text { Амид III; } v_{\text {as }}\left(\mathrm{SO}_{2}\right) \\
\text { в сульфатах }\end{array}$ \\
\hline 1172 & 1168 & 1170 & - & 1174 & 1172 & $v\left(\mathrm{C}_{\alpha} \mathrm{N}\right)$ или $\gamma_{t}\left(\mathrm{CH}_{2}\right)$; \\
\hline 1080 & 1084 & 1086 & - & 1080 & 1080 & $v\left(\mathrm{C}_{\alpha} \mathrm{N}\right) ; \mathrm{CH}_{2}$ в циклах \\
\hline $\begin{array}{c}1029- \\
977\end{array}$ & 1029 & $\begin{array}{c}- \\
980\end{array}$ & $\begin{array}{c}1015 \\
-\end{array}$ & $\begin{array}{c}- \\
980\end{array}$ & $\begin{array}{c}- \\
982\end{array}$ & $\begin{array}{l}v_{\mathrm{s}}\left(\mathrm{SO}_{2}\right) \text { в сульфатах; } \\
\text { Амид IV; } \Delta(\mathrm{CO}-\mathrm{NH})\end{array}$ \\
\hline 850 & 852 & 846 & - & 853 & 850 & $\begin{array}{c}\mathrm{CHR}=\mathrm{CHR} ; \gamma_{r}\left(\mathrm{CH}_{2}\right) ; \mathrm{N} \\
\text { и СО вициальные; } \gamma_{w}\end{array}$ \\
\hline 730 & 730 & 724 & 730 & 730 & 732 & $\begin{array}{l}\text { Амид } \mathrm{V} ; \delta_{\mathrm{o}}(\mathrm{NH}) ; \\
v_{\mathrm{s}}(\mathrm{S}=\mathrm{O}) \text { в солях }\end{array}$ \\
\hline $\begin{array}{c}624- \\
520\end{array}$ & $\begin{array}{l}624- \\
536\end{array}$ & $\begin{array}{c}624- \\
531\end{array}$ & $\begin{array}{l}- \\
-\end{array}$ & $\begin{array}{c}623- \\
534\end{array}$ & $\begin{array}{c}623- \\
534\end{array}$ & $\begin{array}{c}\text { Амид VI; } \delta_{0}(\mathrm{C}=\mathrm{O}) \text { широк. } \\
\text { огибающ. полоса в цик- } \\
\text { лах }\end{array}$ \\
\hline
\end{tabular}

Эта задача может быть решена при синтезе полимеров на основе ВК с N,N'-метилен-бис-акриламидом в присутствие ГМПААм. В качестве стабилизатора был выбран высокомолекулярный ПАВ - ГМПААм различной молекулярной массы $\left(0.3 \cdot 10^{6}-1.6 \cdot 10^{6}\right)$. Сополимеризацию ВК с МБААм инициировали персульфатом калия (ПСК) в количестве 1 масс. \%, по отношению ко всей массе исходных веществ. ВК и МБААм (2 масс. \% в расчете к ВК) использовали виде толуольного раствора с 20\%-ной концентрацией. ГМПААм предварительно растворяли в воде. Приготовленный раствор сополимеров диспергировали в растворе ГМПААм ультразвуком, нагревали до $70^{\circ} \mathrm{C}$ и добавляли водный раствор ПСК [24-27]. Контроль по содержанию сомономеров проводился йодометрическим титрованием. Окончание реакции достигалось в течение 6 часов.

Полученная дисперсия диализовалась, контроль по Ђ-потенциалу и $\mathrm{pH}$ (рис. 6). Невысокие значения $\zeta$-потенциала при $\mathrm{pH}<4$ объясняются тем, что в кислых средах -COOH недиссоциированы. При $\mathrm{pH}>4$ в результате протолиза -COOH в полимерных частицах дисперсии накапливаются -COO-группы и величины

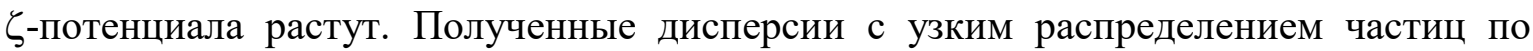
размерам сохраняются в течение длительного времени (рис. 8). Необходимо отметить, что узкое распределение по размерам и высокая стабильность частиц связана с самоорганизацией в процессе полимеризации путем формирования межфазного адсорбционного слоя за счет взаимодействия (супрамолекулярного) групп мономера, сульфогрупп молекул инициатора и амидных групп стабилизатора. В подтверждение этого свидетельствуют данные ИК-спектроскопии (рис. 7, табл. 3).

В ИК-спектрах смеси (ВК+ГМПААм) существенно снижается интенсивность максимумов $1668,1640,1559,1502,1324 \mathrm{~cm}^{-1}$, характерных колебаниям $\mathrm{C}=\mathrm{O}$ (Амид I) и $\delta \mathrm{NH}+\mathrm{C}-\mathrm{N}$ (Амид II), исчезновению полос поглощения 3386, 3352, $1029 \mathrm{~cm}^{-1}$ (Амид IV) и $v_{\mathrm{s}} \mathrm{O} \times \times \times \mathrm{NH}\left(v_{\mathrm{s}} \mathrm{NH} \times \times \times \mathrm{NH}\right)$. Эти факты свидетельствуют об участии карбонильных и NH-групп в супрамолекулярном формировании новых адсорбционных слоев в дисперсиях, а также и их гидрофобизации. 


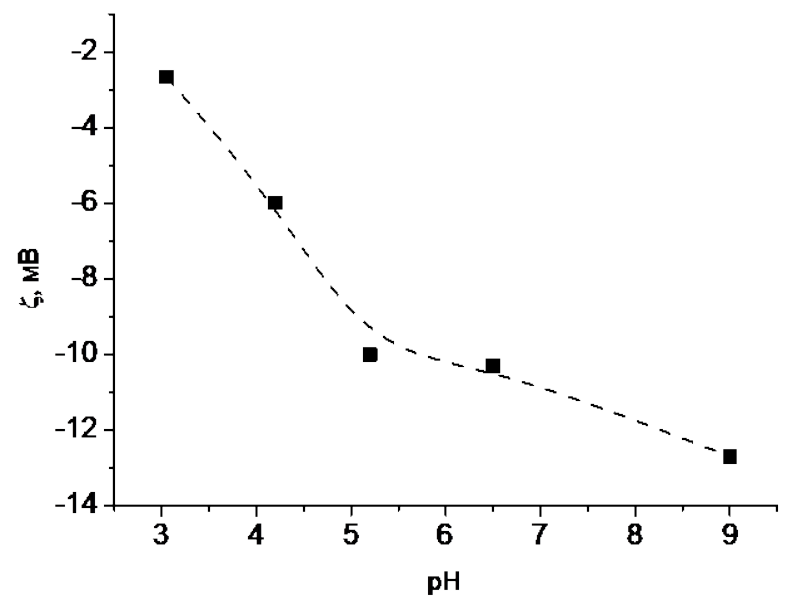

Рис. 6. Влияние $\mathrm{pH}$ на изменение $\zeta$-потенциала частиц полимерной дисперсии поли-N-винилкапролактама

Fig. 6. The influence of the $\mathrm{pH}$ on the change in the $\zeta$-potential of the polymer dispersion particles of poly(N-vinylcaprolactam)

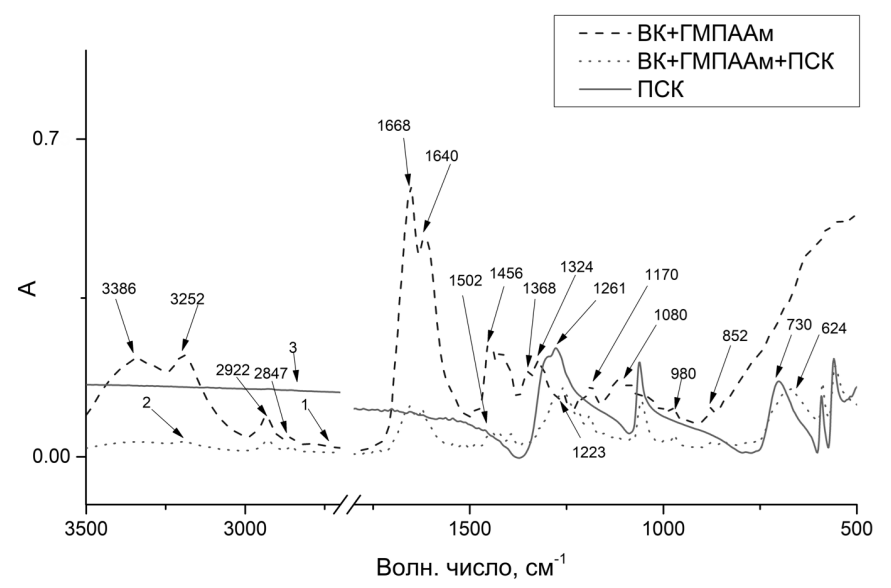

Рис. 7. ИК-спектры смеси (ВК+ГМПААм) (пунктирная линия 1 соответствует линии 3 на рис.6) и в присутствии ПСК (точечная линия 2).

Сплошная кривая 3-линия - персульфат калия

Fig. 7. IR-spectra of the mixture (VCL+HMPAAm) (dashed line 1 is the same as line 3 in Fig. 6) in the presence of PAA (dotted line 2).

Dot-and-dash curve 3 - potassium persulfate

Синтезированные дисперсии стабильны в интервале $3.0 \leq \mathrm{pH} \leq 11.5$. Наряду с этим дисперсии термочувствительны в широком интервале температур от 20 до $55^{\circ} \mathrm{C}$. Наиболее значимым свойством ПВК дисперсий является их повышенная термочувствительность вблизи нормальной температуры человеческого организма.

Аналогичные термочувствительные эмульсии были получены методом гетерофазной сополимеризации ВК и 1-винилимидазола в присутствии ГМПААм, а также ВК и N,N'-диметиламиноэтилметакрилата в качестве поверхностно активного сомономера.

Метод литографии. Метод литографии обеспечивает высокую и постоянную степень контроля в процессе формирования (самосборки) гелей. Этот метод необходим в процессах супрамолекулярной и наномолекулярной химии дисперсий «ум- 
ных» полимеров, которые широко используются в современной диагностике, способах и выборе лечебных процедур, ускорения реакций синтеза гелей.

В работах [23, 28-30] рассмотрен литографический способ синтеза гидрофильного сшитого полимера со свойствами суперабсорбента на основе дисперсии акриловой кислоты, полиакрилата и МБААм и биодеградирующих полисахаридов (крахмала, хитозана, пектина). Указанный умный полимер получил название «Твер-

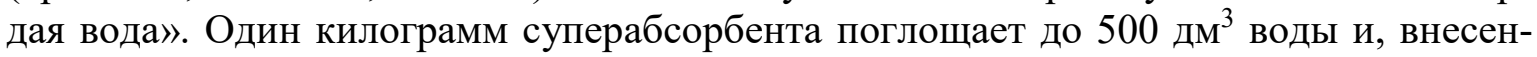
ный при посеве сельхоз-культур в почву, при однократном поливе во время засухи выступает как источник влаги в течение всего вегетационного периода. Для синтеза микроразмерных гелей «Твердая вода» предложены современные методы контроля, что позволило получать суперабсорбенты различных составов и форм.

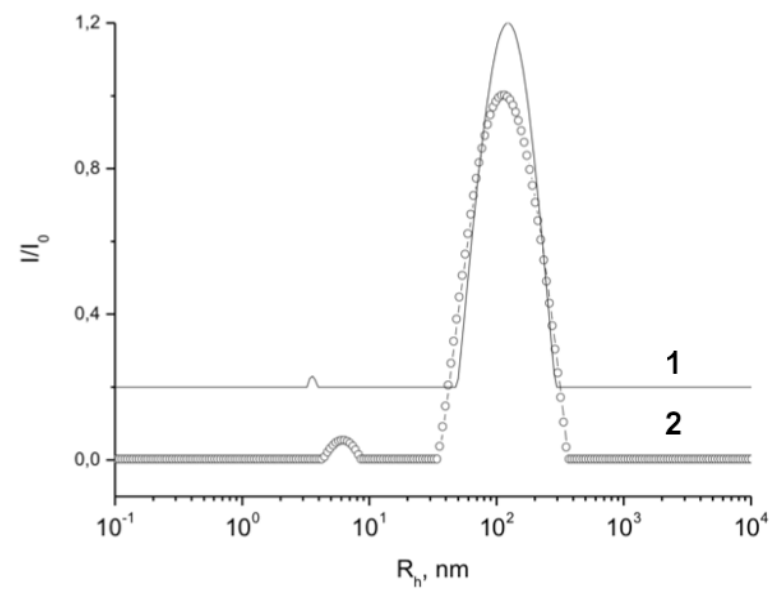

Рис. 8. Влияние временного фактора на распределение размера частиц $\mathrm{R}_{\mathrm{h}}$ полимерных диспресий с $\mathrm{M}_{\mathrm{w}}($ ГМПААм $)=0.5 \cdot 10^{6} .1$ - непосредственно после синтеза; 2 - через месяц после синтеза.

Fig. 8. The influence of time on the size distribution of the particles $R_{h}$ of polymer dispersions with $\mathrm{M}_{\mathrm{w}}(\mathrm{HMPAAm})=0.5 \cdot 10^{6} .1$ - immediately after the synthesis; 2 - one month after the synthesis.

К литографическим методам необходимо отнести способ концентрирвания гидрофобных веществ с использованием субкритической воды [43]. В вышеупомянутом способе предложено использовать нагретую до $200-300^{\circ} \mathrm{C}$ под давлением в несколько десятков атмосфер в качестве элюента для проведения ВЭЖХ разделения или растворителя при выделении гидрофобных органических веществ из лекарственных, фармацевтических препаратов и растительного сырья $[11,43,55,59]$. Температура и давление выбираются ниже критических показателей $\left(\mathrm{T}_{\text {крит }}=374^{\circ} \mathrm{C}\right.$; $p_{\text {крит }}=218$ атм), что не позволяет воде перейти в состояние сверхкритического флюида. Вода остается жидкостью - субкритической водой, а её свойства сопоставимы со свойствами чистых ацетона или метанола.

При высоких температурах растворимость органических компонентов растёт, а при более низких уменьшается и, соответственно, вода становится слабым элюентом. Проведение сорбционного концентрирования в проточных к хроматографических и ионообменных системах при повышенных температурах с последующей десорбцией органических веществ охлаждённый водой, позволяет сконцентрировать десорбируемые соединения в узкой зоне на начальном участке сорбционной колонки, показанной на схеме: 


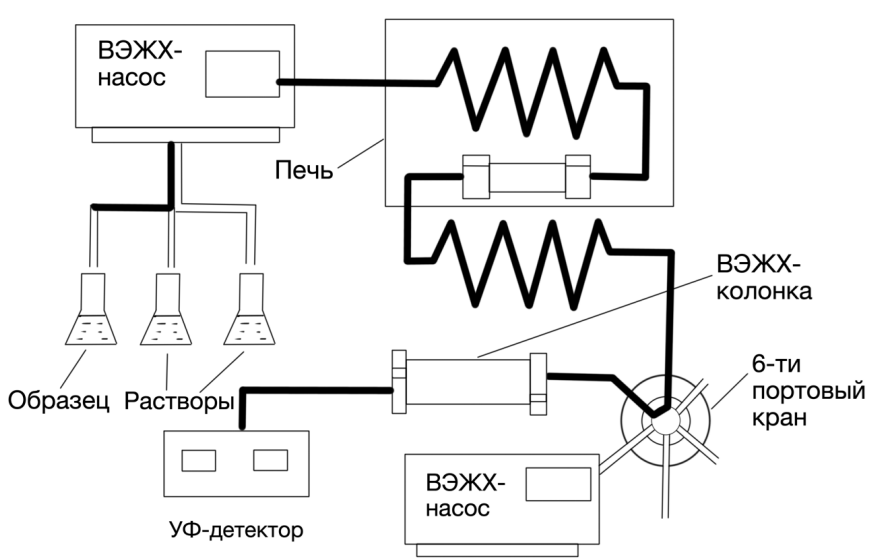

Таблица 4. Ширины пиков при прямом вводе и в проточном сорбционно-ВЭЖХ разделении. $\mathrm{C}_{\text {фенолов }}=10$ мкг/дм ${ }^{3}$; Скорость потока $-1 \mathrm{~cm}^{3} /$ мин. Сорбент «Hypercard» Table 4. The width of the peaks during the direct introduction and flowing sorption-HPLC separation. $\mathrm{C}_{\text {phenols }}=10 \mu \mathrm{g} / \mathrm{l}$; flow speed $-1 \mathrm{ml} / \mathrm{min}$. Hypercard sorbent

\begin{tabular}{|c|c|c|}
\hline $\begin{array}{c}\text { Определяемое } \\
\text { вещество }\end{array}$ & $\begin{array}{c}\text { Ширина пика на } 1 / 2 \text {-высоты при } \\
\text { прямом определении, сек. }\end{array}$ & $\begin{array}{c}\text { l/2-пика на половине высоты при } \\
\text { сорбционном ВЭЖХ определении, } \\
\text { сек }\end{array}$ \\
\hline 1 & 2 & 3 \\
\hline Фенол & 15 & 10 \\
\hline 2-хлорфенол & 21 & 11 \\
\hline 4-нитрофенол & 18 & 16 \\
\hline 2,4-дихлорфенол & 23 & 16 \\
\hline 2,4-диметилфенол & 26 & 20 \\
\hline 2-нитрофенол & 27 & 16 \\
\hline $\begin{array}{c}\text { 4-хлор-3- } \\
\text { метилфенол }\end{array}$ & 30 & 20 \\
\hline
\end{tabular}

*графитовый углеродный сорбент Нуреrсard наиболее устойчив по сравнению с силикагелями и органополимерными сорбентами.

В работе использовались углеродные сорбенты и типа графитированных образцов Hypercard. Данные табл. 4 свидетельствует об уменьшении ширины пиков при фокусировании фенолов из раствора в 1.5-2.0 раза субкритической водой по сравнению с прямым ВЭЖХ-анализом в ацетонитриле (с водно-ацетонитрильной смесью) [43]. Микрофлюидная техника контроля дисперсий биологически активных материалов осложнена, если они взаимодействует с мономером и растворителем.

Типы on-line концентрирования органических аналитов в капиллярном электрофорезе. Методы on-line концентрирование органических веществ в капиллярном электрофорезе также можно отнести к литографическим процессам. Основными вариантами капиллярного электрофореза (КЭ) выступают капиллярные зонный электрофорез (КЗЭ) для фракционирования ионогенных соединений и мицеллярная электрокинетическая хроматография (МЭКХ) для разделения нейтральных и ионных аналитов, которое основано на различии значений констант распределения между рабочим буферным раствором и псевдостационарной мицеллярный фазой $[35,56-$ 59]. Для этого в качестве мицеллообразующих микрореакторов применяют поверхностно активные вещества.

Из наиболее используемых вариантов on-line концентрирование и разделение в капиллярном электрофорезе выделяют: 
1. динамический $\mathrm{pH}$-скачок (dynamic $\mathrm{pH}$ junction);

2. стэкинг (stacking);

3. изотахофоретический стэкинг (самоиндуцируемый изотахофорез, transient isotachophoresis, t-ITP);

4. свипинг (sweeping).

В основе количественной оценки степени концентрирования лежит фактор эффективности концентрирования (SEF - stacking efficiency factor), который рассчитывается по величинам высот ( $\left.\mathrm{SEF}_{\text {height }}\right)$ или площадей $\left(\mathrm{SEF}_{\text {area }}\right)$ :

$$
\mathrm{SEF}_{\text {height }}=\frac{h_{1}}{h_{0}(2 \text { сек })} \cdot \Delta
$$

где $h_{1}, h_{2}$ (2 сек) - высоты пиков, полученных при концентрировании, и при обычном вводе пробы; $\Delta$ - коэффициент разбавления [35].

On-line методы литографии при стэкинге усиленного электрополя в капиллярном электрофорезе. Электроконцентрирования с использованием стэкинга при усилении поля (field-amplified sample stacking - FASS) основан на различиях в электропроводности матрицы образца и буферной рабочей смеси [56-59]. Проба гидродинамически поступает в кварцевый капилляр из раствора с меньшей электропроводностью по сравнению с рабочим буфером (рис. 9) $[35,59,60]$. Ионы раствора с более низкой электропроводностью обладают большей электрофоретической подвижностью, чем в рабочем буферном растворе.

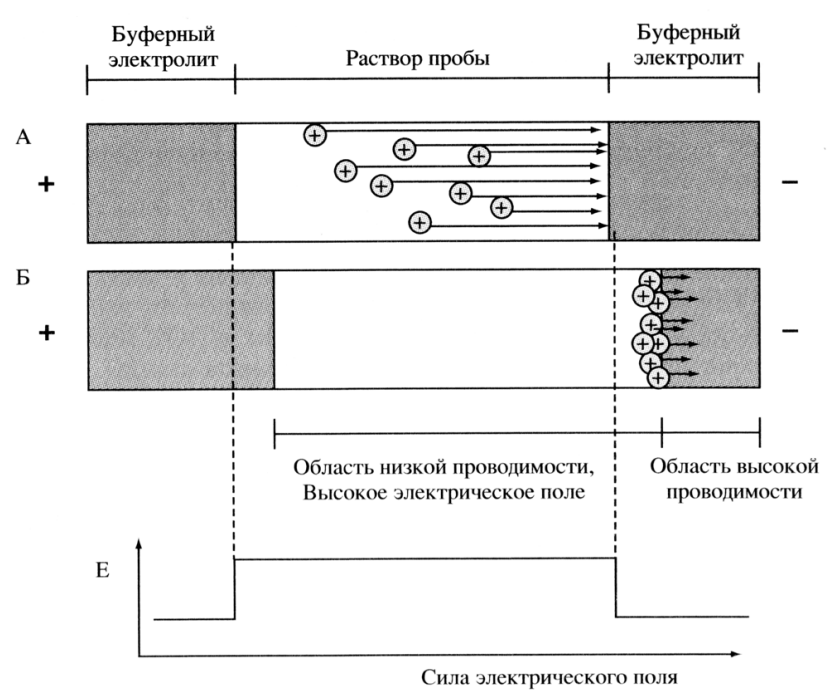

Рис. 9. Схема стэкинга образца с усилением поля (FASS) в капиллярном электрофорезе [10]. А - ввод пробы, растворенной в низкопроводящей матрице (разбавленном буфере или воде). Включение напряжения создает высокое электрическое поле в зоне пробы (Б) остальной части капилляра. Катионы быстро мигрируют в этой области до границы низкого поля в зоне распределительного буфера.

Б - катионы замедляются и концентрируются на границе между зоной пробы и буферным электролитом.

Fig. 9. A scheme of the field-amplified sample stacking (FASS) during the capillary electrophoresis. A - introduction of the sample dissolved in a low conductivity matrix (diluted buffer or water). The voltage creates a high electric field in the zone of the sample (B) of the rest of the capillary. Cations migrate quickly towards the boundary of the low field in the zone of the distribution buffer. B - cations slow down and concentrate on the boundary between the sample zone and the buffer electrolyte. 
Возникшие в зоне пробы сильное электрополе при приложении напряжения концам кварцевого капилляра приводит в движение (с высокой локальной скоростью) аналиты (рис. 9А). При достижении границы рабочего буфера происходит замедление скорости аналитов и они концентрируются в отдельные самостоятельные зоны (рис 9Б). Когда градиент проводимости исчезает, сконцентрированные зоны определяемых веществ приходят к обычному электрофоретическому разделению.

Одной из обязательных особенностей для концентрирования и последующего функционирования катионов является использование положительной полярности электродов и, соответственно, введение пробы с анодного конца капилляра. Проведение анализа методом стэкинга с усилением поля анионов требует использования отрицательной полярности электродов, и ввода пробы с катодного конца капилляра. Использование стэкинга с усилением поля (как увеличение эффективности литографического метода контроля) позволяет увеличить не менее, чем на порядок (то есть в 10 раз) концентрирование пробы. Эффективность концентрирование, пропорциональная степень усиление поля $\gamma$, растёт с увеличением разности концентрации между буферным раствором и раствором пробы, приводя к сужению зоны фракционированной пробы:

$$
L_{\text {stack }}=L_{\text {ввод }} \frac{1}{\gamma}
$$

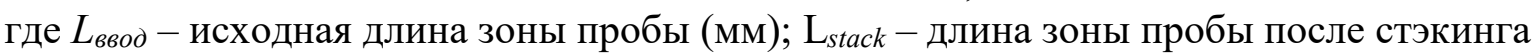
с усилением поля (мм); $\gamma$ - отношение силы электрополей в растворе пробы (S) и буферной смеси (BGS):

$$
\gamma=\frac{E_{S}}{E_{B G S}}
$$

Однако, из-за локальных изменений скорости внутри капилляра появляется ламинарный поток, уменьшающий эффективность стэкинга (дестэкинг) путём размытия сфокусированных зон [35]. Поэтому ограничивают объем вводимой пробы 5 \% объема капилляра, а используемый в качестве растворителя буферный раствор разбавляют в примерно 10 раз. Модификацией этого варианта on-line концентрирования является стэкинг с усилением поля с «водной пробкой» (HC-FASS - headcolumn field-amplified sample stacking). Для формирования (самоорганизации) на входном конце капилляра зоны высокого давления перед непосредственным дозированием пробы вводится «водная пробка». Эта операция позволяет ввести ионсодержащие пробы с высокой скоростью миграции. Электрокинетический ввод пробы приводит к концентрированию аналитов на границе между низкопроводящей зоной пробы анализируемого вещества и буферным электролитом (катионы концентрируются без переключения полюсов; стэкинг-концентрирование анионов использует отрицательную полярность) [35].

В ряде случаев стэкинг с усилением поля комбинируют с off-line или on-line жидкостно-жидкостной микроэкстракцией и твердофазной экстракцией $[35,38,60$, 61], чтобы предочистить и обессолить биологические смеси и увеличить степень концентрирования до 800.

pH-контролируемый стэкинг (pH-mediated stacking). В вышеописанных вариантах стэкинга (3.1-3.2) концентрирование органических ионов ограничено разницы электропроводимостей, обусловленной низкой проводимостью матрицы пробы по сравнению с разделительным буферным раствором. Для анализа биологических смесей с большой концентрацией солей применяется вариант стэкинга, при котором формирование области с низкой электропроводностью внутри зоны пробы осуществляется локальным изменениям рН в капилляре [35, 61-64]. Буферный электро-

Кущев П.О. / Сорбционные и хроматографические процессы. 2020. Т. 20. № 4. С. 493-515 
лит должен содержать соль слабой кислоты (для определения катионов) или основания (при определении анионов).

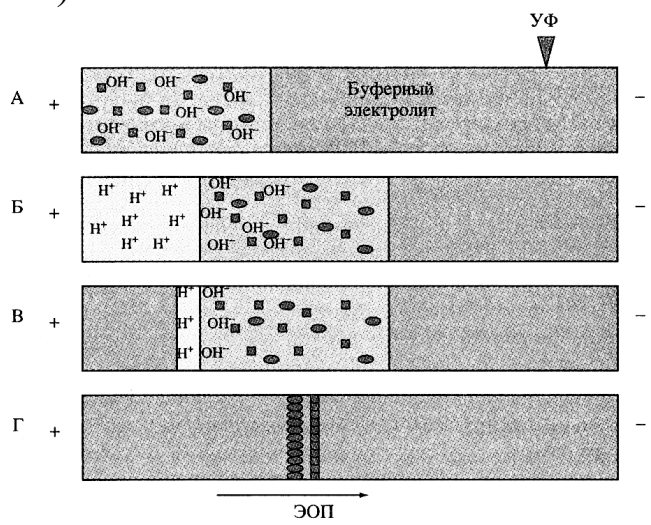

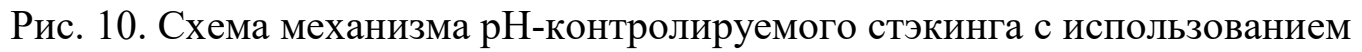
кислоты [10]. А - электрокинетический ввод пробы в капилляр.

Б - электрокинетический ввод сильной кислоты. В - сильная кислота тирует зону пробы до нейтрального значения рН и проводимость в растворе пробы заметно снижается. Г - аналиты концентрируются в узкие зоны на границе тирования и разделяются в условиях КЭФ.

Fig. 10. A scheme of the $\mathrm{pH}$-controlled stacking performed using acid.

A - electrokinetic introduction of the sample in the capillary. B - electrokinetic introduction of strong acid. $\mathrm{C}$ - the strong acid titrates the sample zone to the neutral value of $\mathrm{pH}$, and the conductivity of the sample in the solution reduces significantly. D - analytes concentrate in narrow zones on the titration boundary and are separated under CZE

Раствор аналита с высокой проводимостью электрокинетически вводят в капилляр (рис. 10 а). Затем после замены анионов (катионов) анализируемой смеси на анионы (катионы) буферного электролита электрокинетически вводится сильная кислота (или основание) (рис. 10 б). Происходит нейтрализация раствора пробы, приводящая к снижению его электропроводимости. Результатом этого является установление нейтрального значения $\mathrm{pH}$ (рис.10 в). В зоне пробы образуется зона с высоким электрополем, под действием которого ионы анализируемой пробы убыстряют движение и концентрируются в конце зоны пробы (рис. 10 Г). Разделение компонентов происходит в условиях капиллярного зонного электрофореза (табл. 5). pHконтролируемые варианты стэкинга дают возможность концентрировать и определять только ионные компоненты в биологических смесях. Достигаемая степень концентрирования находится в пределах $10<\mathrm{SEF}_{\text {height }}<1000$ [35].

Таблица 5. .Применение различных вариантов стэкинг-концентрирования в капиллярном электрофорезе

Table 5. Various modes of stacking concentration in capillary electrophoresis.

\begin{tabular}{|c|c|c|}
\hline Аналиты [35] & Матрицы пробы [35] & ПО и/или SEF \\
\hline 1 & 2 & 3 \\
\hline \multicolumn{2}{|c|}{ Стэкинг с усилением поля (FASS, NSM) } \\
\hline $\begin{array}{c}\text { Лекарственные препараты } \\
\text { (опиоиды) }\end{array}$ & $\begin{array}{c}\text { Сыворотка крови, плазма, } \\
\text { моча }\end{array}$ & $0,1 \mathrm{нг} / \mathrm{cm}^{3} \mathrm{SEF} 400$ \\
\hline ДНК & Сыворотка крови & $\mathrm{SEF} 1000$ \\
\hline Биогенные амины & Моча & $14.7-313.4 \mathrm{HM} / \mathrm{дm}^{3}$ \\
\hline Никотин и его производные & Моча & $0.55 \mathrm{Hг} / \mathrm{cm}^{3} \mathrm{SEF} 200$ \\
\hline Фенольные экотоксиканты & Питьевая вода & $0.01 \mathrm{m \Gamma} / \mathrm{дm}^{3}$ \\
\hline
\end{tabular}




\begin{tabular}{|c|c|c|}
\hline 1 & 2 & 3 \\
\hline \multicolumn{3}{|c|}{ рН-контролируемый стэкинг } \\
\hline $\begin{array}{c}\text { Лекарственные препараты } \\
\text { (кокаин, метадон) }\end{array}$ & Биологические объекты & $2 \mathrm{H} \Gamma / \mathrm{cm}^{3}$ \\
\hline $\begin{array}{c}\text { Метаболиты кумарина (1,2- } \\
\text { бензопираена) }\end{array}$ & Биологические объекты & 0.1 мкМ \\
\hline ДНК фрагменты & Биологические объекты & 9 фг/мкл \\
\hline Нуклеозиды & Биологические объекты & мкM \\
\hline Глутатион & Микродиализат & 0.75 мкМ \\
\hline Биогенные амины & Моча & 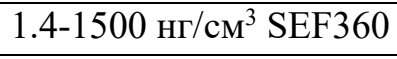 \\
\hline Органические кислоты & Моча & - \\
\hline
\end{tabular}

Ион-селективный стэкинг-свипинг (cation or anion selective exhaustive injection-sweeping, CSEI- or ASEI-sweeping). Ион-селективный стэкинг-свипинг относится гибридным методом концентрирования и представляет собой сочетание двух механизмов концентрирования: стэкинг с усилением поля (FESI) и электрокинетическим вводом большого объема пробы в сочетании со свипингом [35, 58, 65]. Поэтому необходимо пояснить основные положения концентрирования при свипинге:

-Отсутствие псевдостационарной фазы в растворе пробы;

-Проводимость раствора образца, в отличие от стэкинга, должна быть близка проводимости рабочего электролита, что обеспечивает однородное электрополе внутри капилляра [35].

Применение стэкинг-свипинг гибридного концентрирование позволяет увеличить чувствительность детектирования в 100000 раз, но селективно сконцентрировать можно либо катионы, либо анионы.

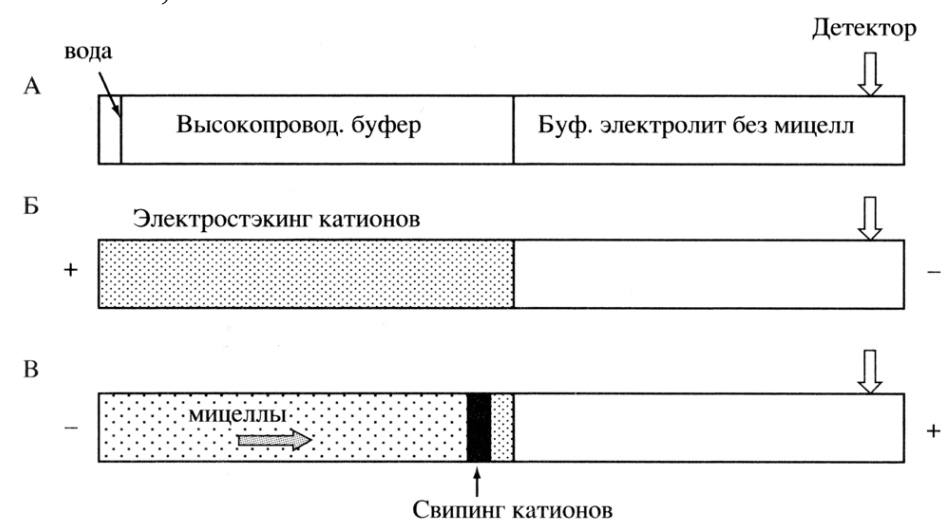

Рис. 11. Схема стэкинга-свипинга катионов [10]

Fig. 11. A scheme of cation stacking-sweeping

Перед вводом пробы на концентрирование катионов капилляр заполняется буферным электролитом высокой проводимости. При этом мицеллы в буферном растворе отсутствуют. После заполнения капилляра буфером, в капилляр вводят небольшой объем водной пробки для усиления электрополя на конце капилляра (рис. 11 a). При положительном напряжении электрокинетически вводится большой объем пробы (400 c), растворённый в низко проводящей матрице (рис. 11 Б). Катионы пробы селективно и с большой скоростью мигрируют в капилляр в зоне водной пробки и, по достижении (рис.10 В) границы между водой и высокопроводящим буферным электролитом, замедляют скорость и концентрируются [58, 65]. Последующий процесс электрокинетического ввода образует зону сконцентрированного об- 
разца. После ввода пробы концы капилляра отпускают в буферный раствор с мицеллами (рис.10 В) и подают напряжение при отрицательной полярности. Мицеллы, поступая в зону пробы, вызывают концентрирование её компонентов. Материалы по использованию метода стэкинг-свипинга приведены в табл. 6.

Таблица 6. Применение ион-селективного стэкинг-свипинга в вариантах концентрирования при анализе конкретных объектов

Table 6. Ion-selective stacking-sweeping in various concentration modes during the analysis of specific objects

\begin{tabular}{|c|c|c|}
\hline Аналиты [35] & Матрицы пробы $[65,66]$ & $\Pi О$ \\
\hline $\begin{array}{c}\text { Катехин, фенольные кисло- } \\
\text { ты, галловая кислота }\end{array}$ & Продукты питания & $3 \mathrm{нг} / \Gamma$ \\
\hline Производные меламина & Молоко & SEF 6000-9000 \\
\hline Гербициды & Питьевая вода $<1$ мкг/дм ${ }^{3}$ & SEF 50000 \\
\hline Метадон & Биологические жидкости & $200 \mathrm{H \Gamma} / \mathrm{cm}^{3}$ \\
\hline $\begin{array}{c}\text { Запрещенные лекарства ке- } \\
\text { тамин, кодеин, морфин }\end{array}$ & Волосы, моча 50-200 нг/мг & $5-15 \mathrm{Hг} / \mathrm{cm}^{3}$ \\
\hline Ароматические амины & Окружающая среда & нг/дм ${ }^{3}$; SEF $10^{5}$ \\
\hline $\begin{array}{c}\text { Пенициллиновые антибиоти- } \\
\text { ки }\end{array}$ & Биологические объекты & $2.8-5.8$ мкг/дм ${ }^{3}$ \\
\hline Фенольные кислоты & Моча & SEF 3400 \\
\hline
\end{tabular}

\section{Заключение}

Проведён выбор поверхностно активных веществ для стабилизации дисперсий «умных» полимеров на основе N-винилкапролактама. Экспериментально подтверждено, что при гетерофазной полимеризации N-винилкапролактама и N,N'метилен-бис-акриламида с низкомолекулярными ПАВ не удалось синтезировать устойчивые дисперсии. Устойчивые во времени и под влиянием температурных электрокинетических и протолитических характеристик дисперсии Nвинилкапролактама были получены при сополимеризации с полиакриламидом, модифицированным моностеаратом сорбитана.

Показано, что устойчивые полимерные дисперсии N-винилкапролактама методами гетерофазной гомо- и сополимеризации получаются только при образовании новой фазы в виде полимерного адсорбционного слоя в результате супрамолекулярных процессов функциональных групп мономера с амидными группами стабилизатора. Наличие указанных процессов подтверждено методами динамического светорассеяния, просвечивающей электронной микроскопии и ИК-спектроскопии.

Установлены гидродинамические радиусы частиц полимерной дисперсии поли-N-винилкапролактама, являющиеся оптимальными и сохраняющими термочувствительность, протолитическую и электрокинетическую чувствительность в течение нескольких месяцев.

Разработан способ синтеза агрегативно устойчивых дисперсий $\mathrm{N}$ винилкапролактама и его сополимеров с 1-винилимидазолом с узким контролируемым распределением частиц по размерам. Синтез ведется в присутствии полиакриламида, модифицированного моностеаратом сорбитана (как стабилизатора гетерофазной полимеризации). Способ синтеза защищен патентом РФ [24] №2569377-С1.

Проведён анализ экспериментальных данных по методу литографии, обеспечивающего постоянную степень контроля в процессе самосборки дисперсий «умных» полимеров. Показана перспективность применения микроразмерных гелей на 
основе полиэтиленгликоля и полиамидов в капиллярном зонном электрофорезе для разделения ионогенных соединений и мицеллярной электрокинетической хроматографии для разделения нейтральных ионных аналитов.

\section{Список литературы}

1. DeRossi D., Kajiwara K., Osada Y., Yamauchi A. // Polymer Gels: Fundamentals and Biomedical Applications. Boston. MA. Springer US. $1991.354 \mathrm{p}$

2. Harland R.S., Prud'homme R.K. // Eds. Polyelectrolyte Gels: Properties, Preparation, and Applications. Washington, DC, American Chemical Society. 1992. 450 p.

3. Kabanov A.V., Vinogradov S.V. // Angew. Chem. Int. Ed. 2009. Vol. 48. No 30. pp. 54185429. DOI: 10.1002/anie.200900441.

4. Pich A., Richtering W. // Polymer Nanogels and Microgels. In Polymer Science: A Comprehensive Reference. 2012. Vol. 6. pp. 309-350.

5. Yallapu M.M., Reddy M.K., Labhasetwar V. // Nanogels: Chemistry to Drug Delivery. In Biomedical Applications of Nanotechnology. 2007. pp. 131-171.

6. Яминский В.В., Пчелин В.А., Амелина Е.А., Щукин Е.Д. Коагуляционные контакты в дисперсных системах. М. Химия. 1982. 185 c.

7. Рыжкина И.С., Муртазина Л.И., Киселева Ю.В., Коновалов А.И. // ДАН. 2009. Т. 428. № 4. C. 487-491.

8. Штыков С.Н. Люминесцентный анализ в организованных средах / В кн. «Люминесцентный анализ». Проблемы аналитической химии. М. Наука. 2015. Т.19. С. 121-155.

9. Даванков В.А., Навратил Д., Уолтон Х. Лигандообменная хроматография. М. Мир. 1989. $294 \mathrm{c}$.

10. Чернова Р.К., Доронин С.Ю. Определение органических аналитов в растворах ПАВ: ионные и мицеллярные эффекты. Саратов. Изд. Саратовского гос. ун-та. 2017. $200 \mathrm{c}$.

11. Сумина Е.Г. Мицеллы поверхностноактивных веществ в жидкостной хроматографии / В кн. «Нанообъекты и нанотехнологии в химическом анализе. Проблемы аналитической химии». М. Наука. 2015. Т. 20. С. 267-305.

12. Бретшнайдер Ст. Свойства газов и жидкостей. М. Ленинград. Химия. 1966. 535 с.

13. Ульянов А.В., Полунина И.А., Полунин К.Е., Буряк А.К. // Сорбиионные и хромато- графические проиессы. 2019. Т. 19. № 2. С. 130-138. DOI: https://doi.org/10.17308/ sorpchrom.2019.19/730

14. Платонов И.А., Платонов Вл.И., Платонов Вал.И., Ворон С.В. // Сорбиионные и хроматографические проиессы. 2019. Т. 19. № $2 . \quad$ C. $168-173$. DOI: https://doi.org/10.17308/sorpchrom.2019.19/734

15. Шкутина И.В., Мироненко Н.В., Селеменев В.Ф. // Сорбиионные и хроматографические проиессы. 2019. Т. 19. № 1. С. 2329. DOI: https://oi.org/10.17308/sorpchrom.2019.19/644

16. Долгоносов А.М., Хамизов Р.Х., Колотилина Н.К., Шайхина С.У. и др. // Сорбционные и хроматографические прочессы. 2016. T. 16. № 4. C.400-414.

17. Белякова Н.В., Нечаева Л.С., Бутырская Е.В., Шапошник В.А. и др. // Сорбиионные и хроматографические проиессы. 2016. Т. 16. № 4. C.526-532.

18. Крачак А.Н., Хамизов Р.Х., Кузьминова И.Г. // Сорбиионные и хроматографические nроиессы. 2016. Т. 16. № 1. С.8-16.

19. Семенов В.Н., Зенищева А.В., Селеменев В.Ф., Кузнецов В.А. и др. // Сорбиионные и хроматографические проиессы. 2018. T. 18 . № $5 . \quad$ C.690-695. DOI: https://doi.org/10.17308/sorpchrom.2018.18/59 5

20. Беланова Н.А., Карпов С.И., Синяева Л.А., Селеменев В.Ф. и др. // Сорбиионные и хроматографические проиессы. 2018. Т. 18. № 2. C. 160-169.

21. Цурюпа М.П., Блинникова 3.К., Давидович Ю.А., Даванков В.А. // Сорбиионные $и$ хроматографические проиессы. 2016. Т. 16. № 5. С.582-590.

22. Думанский А.В. Учение о коллоидах. М. Ленинград. Гос. научно-техническое издво хим. лит. 1948.416 с.

23. Кузнецов В.А., Селеменев В.Ф., Семенов В.Н., Бакалова М.В. Патент РФ № 2574722. Опубл. 10.02.2016 БИ №4.

24.Кущев П.О., Кузнецов В.А. Патент РФ № 2569377. Опубл. 27.11.2015 БИ № 33.

25. Kuznetsov V.A., Kushchev P.O., Blagodatskikh I.V., Ostankova I.V. et al. // 
Colloid Polym. Sci. 2016. Vol. 294. No 5. pp. 889-899. DOI: $10.1007 / \mathrm{s} 00396-016-3843-5$.

26. Кущев П.О., Кузнецов В.А., Шаталов Г.В., Благодатских И.В. и др. // Сорбиионные и хроматографические прочессы. 2015. Т. 15. № 1. С. 60-66.

27. Кущев П.О., Саприна Е.И., Кузнецов В.А. // Конденсированные среды и межфазные гранииьл. 2018. Т. 20. № 2. С. 231-236. DOI: $10.17308 / \mathrm{kcmf} .2018 .20 / 527$

28. Зенищева А.В., Семенов В.Н., Кузнецов В.А., Кущев П.О. и др. // Сорбиионные и хроматографические проиессы. 2020. Т. 20. № 2. C. 284-298. DOI: 10.17308/sorpchrom. 2020.20/2784

29. Селеменев В.Ф., Карпов С.И., Беланова Н.А., Рудакова Л.В. и др. // Сорбционные и хроматографические процессы. 2020. Т. 20. № 4. C. 454-476.

30. Зенищева А.В., Семенов В.Н., Кузнецов В.А., Кущев П.О. // Конденсированные среды и межфазные гранииыл. 2020. № 1. С. 66-74.

31. Селеменев В.Ф., Рудаков О.Б., Мироненко Н.В., Семенов В.Н. и др. // Конденсированные среды и межфазные гранииы. 2020. № 3. C. 412-419.

32. Селеменев В.Ф., Орос Г.Ю., Железной С.А., Рудаков О.Б. и др. Патент РФ № 2169734. Опубл. 27.06.2001.

33. Котова Д.Л., Яценко О.Б., Селеменев В.Ф., Бейлина Д.С. и др. Патент РФ № 2214996. Опубл. 27.10.2003.

34. Хохлов В.Ю., Селеменев В.Ф., Хохлова О.Н., Мануковская А.Н. и др. Патент РФ № 2155747. Опубл. 10.09.2000.

35. Бессонова Е.А., Карцова Л.А. Капиллярная электрохроматография / В кн. «Капиллярный электрофорез. Проблемы аналитической химии». М. Наука. 2014. Т. 18. С. 200-262.

36. Смирнова Т.Д., Штыков С.Н. Перенос энергии в наносиситемах: применения в люминисцентном анализе / В кн. «Нанообъекты и нанотехнологии в химическом анализе. Проблемы аналитической химии». М. Наука. 2015. T. 20. C.123-150.

37. Русанова Т.Ю. Нанопленки как чувствительные элементы химических и биохимических сенсоров / В кн. «Нанообъекты и нанотехнологии в химическом анализе. Проблемы аналитической химии. М. Наука. 2015. T. 20. C. 98-122.

38. Туркова Я. Аффинная хроматография. М. Мир. 1980. 472 c.
39. Дэвени Т., Гергей Я. Аминокислоты, пептиды и белки. М. Мир. 1976. 368 с.

40. Жеребцов Н.А., Попова Т.Н., Артюхов В.Г. Биохимия. Воронеж. Изд-во ВГУ. 2002. $696 \mathrm{c}$.

41. Мироненко Н.В., Селеменев В.Ф., Артюхов В.Г., Лавриненко И.А. Сапонины. Воронеж. Издат. полиграфичекий центр «Научная книга». 2019. 205 с.

42. Пирогов А.В. Мицеллярная и микроэмульсионная электрохимическая хроматография / В кн. «Капиллярный электрофорез. Проблемы аналитической химии». М. Наука. 2014. Т. 18. С. 126-199.

43. Цизин Г.И., Статкус М.А. Сорбционное концентрирование микрокомпонентов в динамических условиях. М. Ленинград. 2016. $480 \mathrm{c}$.

44. Wang B., Hong Y., Feng J., Gong Y. et al. // Macromol. Rapid Commun. 2007. Vol. 28. No 5. pp. 567-571. DOI: 10.1002/marc. 200600730. 45. Васияров Г.Г., Дробь А.А., Титова Е.В., Староверов С.М. // Сорбиионные и хроматографические процессы. 2016. Т. 16. № 4. C.488-495.

46. Li Y-Y., Zhang X.-Z., Kim G.-C., Cheng H. et al. // Small. 2006. Vol. 2. No 7. pp. 917923.

47. Sjöblom J., Lindberg R., Friberg S.E. // Adv. Colloid Interface Sci. 1996. Vol. 65. pp. 125-287. DOI: 10.1016/0001-8686(96)00293-X.

48. Zhuang J., Gordon M. R., Ventura J., Li L. et al. // Chem. Soc. Rev. 2013. Vol. 42. No 17. pp. 7421-7435. DOI: $10.1039 / \mathrm{c} 3 \mathrm{cs} 60094 \mathrm{~g}$.

49. Пиментел Дж., Мак-Клеллан О. Водородная связь. М. Мир. 1964. $462 \mathrm{c.}$

50. Селеменев В.Ф. Рудаков О.Б., Славинская Г.В., Дроздова Н.В. Пигменты пищевых производств. Меланоидины. М. ДеЛи принт. 2008. $246 \mathrm{c}$.

51. Дехант И., Данц Р., Киммер В., Шмольке Р. Инфракрасная спектроскопия полимеров. М. Химия. 1976. 472 с.

52. Crespy D., Zuber S., Turshatov A., Landfester K. et al. // J. Polym. Sci. Part Polym. Chem., 2012. Vol. 50. No 6. pp. 1043-1048. DOI: $10.1002 /$ pola.25875.

53. Yi P., Wang Y., Zhang S., Zhan Y. et al. // Carbohydr. Polym. 2017. Vol. 166. pp. 219227. DOI: 10.1016/j.carbpol.2017.02.107.

54. Schramm L., Emulsion, foams and suspensions: fundamentals and applications. Wiley. 2005. $448 \mathrm{p}$.

55. Тиноко И., Зауэр К., Вэнг Дж., Паглиси Дж. Физическая химия. Принциипы и приме- 
нение в биологических науках. М. Техносфеpa. 2005. $744 \mathrm{c}$.

56. Quirino J.P., Terabe S. // J. Chromatogr A. 2000. Vol. 902. pp. 119-135.

57. Arnett S.D., Lunte C.E. // Electrophoresis. 2003. Vol. 24. pp. 1745-1752.

58. Quirino J.P., Terabe S. // Anal. Chem. 2000. Vol. 72. pp. 1023-1030.

59. Морис П. Поверхность и межфазные границы в окружающей среде от наноуровня к глобальному масштабу. М. Бином. лаб. Знаний. 2013. 540 с.

60. Leung S.-A., de Mello A.J. // J. Chroma- togr A. 2002. Vol. 979. pp. 171-178.

61. Duan J., Hy B., He M. // Electrophoresis.

2012. Vol. 33. pp. 2953-2960.

62. Arnett S.D., Lunte C.E. // Electrophoresis.

2007. Vol. 28. pp. 3786-3793.

63. Kamentsev M.Ya., Kamentsev Ya.S., Moskvin L.N., Yakimova N.M. // J. Anal. Chem. 2011. Vol. 66. pp. 212-214.

64. Huang H., Chen Z., Yan X. // J. Sep. Sci. 2012. Vol.35. pp. 436-444.

65. Aranas A.T., Guidote A.M., Quirino J.P. // Anal. Bioanal. Chem. 2009. Vol. 394. pp. 175185.

\title{
Dispersions of "smart" polymers
}

\author{
(C) 2020 Kuschev P.O.
}

Voronezh State University, Voronezh

The article describes the search for surface-active materials (SAM) acting as dispersion stabilisers for "smart" polymers based on N-vinylcaprolactam. In our study, we obtained stable dispersions that react to variable (repeated) changes, namely in pressure, temperature, $\mathrm{pH}$-medium, buffering capacity, voltage, current strength, surface tension, conformation of polymer chains, hydrogen, and dispersion bonds, stacking and sweeping concentrations, and moisture absorption. The dispersions were obtained by means of homopolymerisation of $\mathrm{N}$-vinylcaprolactam and its copolymerisation with 1-vinylimidazole or N,NDimethylaminoethyl methacrylate using a high molecular weight polyacrylamide stabiliser modified with sorbitan monostearate, and copolymerisation of acrylamide, acrylic acid, and polysaccharides (starch, pectin, chitosan), etc.

The study determined that stable polymer dispersions of N-vinylcaprolactam by means of heterophase polymerization are only possible when a new phase is formed in the form of polymer adsorption layers. In some cases, these layers form micelles and micellar microreactors resulting from supramolecular processes between the functional groups of the monomer, the amide groups of the stabiliser, and the polysaccharide. The presence of supramolecular processes during copolymerisation is proved by the results of transmission electron microscopy, dynamic light scattering, and IR spectroscopy.

It was demonstrated that the hydrodynamic radii of the polymer dispersion particles of poly $(\mathrm{N}-$ vinylcaprolactam) change when heated at a temperature within the set range $\left[\left(R_{h} / R_{h} \min \right)=1.2-1.0\right]$, and the particles remain thermally, electrokinetically, and protolytically sensitive for several months.

We also developed a method for synthesising aggregate stable dispersions of N-vinylcaprolactam and its copolymers with 1-vinylimidazole or N,N-Dimethylaminoethyl methacrylate with a narrow controlled particle size distribution. The synthesis is performed using polyacrylamide modified with sorbitan monostearate (RF patent No. 2569377 C1).

The article provides the data concerning the lithography techniques used during the synthesis of "smart" polymers ensuring constant control during the self-assembly of the dispersions. The methods of amplified electric field, pH-controlled stacking, and ion-selective stacking-sweeping in capillary zone electrophoresis are effective for separating the cations, anions, and neutral molecules with organic matrices.

Keywords: polymer dispersion, nanogel, microgel, stimulus sensitivity, cross-linking.

\section{References}

1. DeRossi D., Kajiwara K., Osada Y., US, 1991. 354 p.

Yamauchi A., Polymer Gels: Fundamentals and 2. Harland R.S., Prud'homme R.K., Eds. Biomedical Applications. Boston, MA, Springer Polyelectrolyte Gels: Properties, Preparation, 
and Applications. Washington, DC, American Chemical Society, 1992, $450 \mathrm{p}$.

3. Kabanov A.V., Vinogradov S.V., Angew. Chem. Int. Ed., 2009, Vol. 48, No 30, pp. 54185429. DOI: 10.1002/anie.200900441.

4. Pich A., Richtering W., Polymer Nanogels and Microgels. In Polymer Science: A Comprehensive Reference, 2012, Elsevier, pp. 309-350.

5. Yallapu M.M., Reddy M.K., Labhasetwar V., Nanogels: Chemistry to Drug Delivery. In Biomedical Applications of Nanotechnology, 2007, Hoboken, NJ, USA, John Wiley \& Sons, Inc., pp. 131-171.

6. Yaminskii V.V., Pchelin V.A., Amelina E.A., Shchukin E.D Koagulyatsionnye kontakty v dispersnykh sistemakh, M., Khimiya, 1982, $185 \mathrm{p}$.

7. Ryzhkina I.S., Murtazina L.I., Kiseleva Yu.V., Konovalov A.I., DAN, 2009, Vol. 428, No 4, pp. 487-491.

8. Shtykov S.N. Lyuminestsentnyi analiz v organizovannykh sredakh / In book «Lyuminestsentnyi analiz», Problemy analiticheskoi khimii, M., Nauka, 2015, Vol. 19, pp. 121-155.

9. Davankov V.A., Navratil D., Uolton Kh. Ligandoobmennaya khromatografiya, M., Mir, 1989, $294 \mathrm{p}$.

10. Chernova R.K., Doronin S.Yu. Opredelenie organicheskikh analitov $\mathrm{v}$ rastvorakh PAV: ionnye i mitsellyarnye effekty, Saratov, Izd. Saratovskogo gos. un-ta, 2017, 200 p.

11. Sumina E.G., Mitselly poverkhnostnoaktivnykh veshchestv $\mathrm{v}$ zhidkostnoi khromatografii / In book «Nanoob"ekty i nanotekhnologii $\mathrm{v}$ khimicheskom analize. Problemy analiticheskoi khimii, M., Nauka, 2015, Vol. 20, pp.267305 .

12. Bretshnaider St., Svoistva gazov i zhidkostei, M., Leningrad, Khimiya, 1966, 535 p.

13. Ul'yanov A.V., Polunina I.A., Polunin K.E., Buryak A.K., Sorbtsionnye $i$ khromatograficheskie protsessy, 2019, Vol. 19, No 2, pp. 130-138. DOI: https:/doi.org/10.17308/ sorpchrom.2019.19/730

14. Platonov I.A., Platonov V1.I., Platonov Val.I., Voron S.V., Sorbtsionnye i khromatograficheskie protsessy, 2019, Vol. 19, No 2, pp. 168-173. DOI: https://doi.org/10.17308/sorpchrom. 2019.19/734

15. Shkutina I.V., Mironenko N.V., Selemenev V.F., Sorbtsionnye i khromatograficheskie protsessy, 2019, Vol. 19, No 1, pp.23-29. DOI: $\quad$ https://doi.org/10.17308/sorpchrom.
16. Dolgonosov A.M., Khamizov R.Kh., Kolotilina N.K., Shaikhina S.U. et al., Sorbtsionnye i khromatograficheskie protsessy, 2016, Vol. 16, No 4, pp. 400-414.

17. Belyakova N.V., Nechaeva L.S., Butyrskaya E.V., Shaposhnik V.A. et al., Sorbtsionnye i khromatograficheskie protsessy, 2016, Vol. 16, No 4, pp.526-532.

18. Krachak A.N., Khamizov R.Kh., Kuz'minova I.G., Sorbtsionnye i khromatograficheskie protsessy, 2016, Vol. 16, No 1, pp. 8-16.

19. Semenov V.N., Zenishcheva A.V., Selemenev V.F., Kuznetsov V.A. et al., Sorbtsionnye i khromatograficheskie protsessy, 2018, Vol. 18, No 5, pp. 690-695. DOI: https://doi.org/10.17308/sorpchrom.2018.18/59 5

20. Belanova N.A., Karpov S.I., Sinyaeva L.A., Selemenev V.F. et al., Sorbtsionnye $i$ khromatograficheskie protsessy, 2018, Vol. 18, No 2, pp. 160-169.

21. Tsuryupa M.P., Blinnikova Z.K., Davidovich Yu.A., Davankov V.A., Sorbtsionnye $i$ khromatograficheskie protsessy, 2016, Vol. 16, No 5, pp.582-590.

22. Dumanskii A.V. Uchenie o kolloidakh, M., Leningrad, Gos. nauchno-tekhnicheskoe izd-vo khim. lit., 1948, 416 p.

23. Kuznetsov V.A., Selemenev V.F., Semenov V.N., Bakalova M.V. Patent RF № 2574722. Opubl. 10.02.2016 BI No4.

24.Kushchev P.O., Kuznetsov V.A. Patent RF № 2569377. Opubl. 27.11.2015 BI No 33 .

25. Kuznetsov V. A., Kushchev P. O., Blagodatskikh I. V., Ostankova I. V. et al., Colloid Polym. Sci., 2016, Vol. 294, No 5, pp. 889-899. DOI: $10.1007 / \mathrm{s} 00396-016-3843-5$.

26. Kushchev P.O., Kuznetsov V.A., Shatalov G.V., Blagodatskikh I.V. et al., Sorbtsionnye $i$ khromatograficheskie protsessy, 2015, Vol. 15, No 1, pp. 60-66.

27. Kushchev P.O., Saprina E.I., Kuznetsov V.A., Kondensirovannye sredy $i$ mezhfaznye granitsy, 2018, Vol. 20, No 2, pp. 231-236. DOI: $10.17308 / \mathrm{kcmf} .2018 .20 / 527$

28. Zenishcheva A.V., Semenov V.N., Kuznetsov V.A., Kushchev P.O. et al., Sorbtsionnye $i$ khromatograficheskie protsessy, 2020, Vol. 20, No 2, pp. 284-298. DOI: 10.17308 /sorpchrom.2020.20/2784

29. Selemenev V.F., Karpov S.I., Belanova N.A., Rudakova L.V. et al., Sorbtsionnye $i$ khromatograficheskie protsessy, 2020, Vol. 20, No 4, pp. 545-476. $2019.19 / 644$ 
30. Zenishcheva A.V., Semenov V.N., Kuznetsov V.A., Kushchev P.O., Kondensirovannye sredy i mezhfaznye granitsy, 2020, No 1, pp.6674.

31. Selemenev V.F., Rudakov O.B., Mironenko N.V., Semenov V.N. et al., Kondensirovannye sredy i mezhfaznye granitsy, 2020, No 3, pp. 412-419.

32. Selemenev V.F., Oros G.Yu., Zheleznoi S.A., Rudakov O.B. et al. Patent RF № 2169734. Opubl. 27.06.2001.

33. Kotova D.L., Yatsenko O.B., Selemenev V.F., Beilina D.S. et al. Patent RF № 2214996. Opubl. 27.10.2003.

34. Khokhlov V.Yu., Selemenev V.F., Khokhlova O.N., Manukovskaya A.N. et al. Patent RF № 2155747. Opubl. 10.09.2000.

35. Bessonova E.A., Kartsova L.A. Kapillyarnaya elektrokhromatografiya / In book «Kapillyarnyi elektroforez. Problemy analiticheskoi khimii, M., Nauka, 2014, Vol. 18, pp.200-262.

36. Smirnova T.D., Shtykov S.N. Perenos energii $\mathrm{v}$ nanosisitemakh: primeneniya $\mathrm{v}$ lyuministsentnom analize / In book «Nanoob"ekty i nanotekhnologii v khimicheskom analize. Problemy analiticheskoi khimii, M., Nauka, 2015, Vol. 20, pp.123-150.

37. Rusanova T.Yu. Nanoplenki kak chuvstvitel'nye elementy khimicheskikh i biokhimicheskikh sensorov / In book «Nanoob"ekty i nanotekhnologii v khimicheskom analize. Problemy analiticheskoi khimii, M., Nauka, 2015, Vol. 20, pp. 98-122.

38. Turkova Ya. Affinnaya khromatografiya, M., Mir, 1980, 472 p.

39. Deveni T., Gergei Ya. Aminokisloty, peptidy i belki, M., Mir, 1976, 368 p.

40. Zherebtsov N.A., Popova T.N., Artyukhov V.G. Biokhimiya, Voronezh, Izd-vo VGU, 2002, $696 \mathrm{p}$

41. Mironenko N.V., Selemenev V.F., Artyukhov V.G., Lavrinenko I.A., Saponiny, Voronezh, Izdat. poligrafichekii tsentr «Nauchnaya kniga», 2019, $205 \mathrm{p}$.

42. Pirogov A.V. Mitsellyarnaya i mikroemul'sionnaya elektrokhimicheskaya khromatografiya / V kn. «Kapillyarnyi elektroforez. Problemy analiticheskoi khimii. Moscow, Nauka, 2014, Vol. 18, pp. 126-199.

43. Tsizin G.I., Statkus M.A., Sorbtsionnoe kontsentrirovanie mikrokomponentov v dinamicheskikh usloviyakh, M., , 2016, 480 p.

44. Wang B., Hong Y., Feng J., Gong Y., Gao C., Macromol. Rapid Commun., 2007, Vol. 28, No 5, pp. 567-571. DOI: 10.1002/marc.200600730.

45. Vasiyarov G.G., Drob' A.A., Titova E.V., Staroverov S.M., Sorbtsionnye $i$ khromatograficheskie protsessy, 2016, Vol. 16, No 4, pp. 488-495.

46. Li Y-Y., Zhang X.-Z., Kim G.-C., Cheng H. et al., Small, 2006, Vol. 2, No 7, pp.917923.

47. Sjöblom J., Lindberg R., Friberg S.E., $A d v$. Colloid Interface Sci., 1996, Vol. 65, pp. 125287. DOI: 10.1016/0001-8686(96)00293-X.

48. Zhuang J., Gordon M.R., Ventura J., Li L. et al., Chem. Soc. Rev., 2013, Vol. 42, No 17, pp. 7421-7435. DOI: 10.1039/c3cs60094g.

49. Pimentel Dzh., Mak-Klellan O. Vodorodnaya svyaz', M., Mir, 1964, $462 \mathrm{p}$.

50. Selemenev V.F. Rudakov O.B., Slavinskaya G.V., Drozdova N.V., Pigmenty pishchevykh proizvodstv. Melanoidiny, M., DeLi print, 2008, 246 p.

51. Dekhant I., Dants R., Kimmer V., Shmol'ke R., Infrakrasnaya spektroskopiya polimerov, M., Khimiya, 1976, 472 p.

52. Crespy D., Zuber S., Turshatov A., Landfester K. et al., J. Polym. Sci. Part Polym. Chem., 2012, Vol. 50, No 6, pp. 1043-1048. DOI: 10.1002/pola.25875.

53. Yi P., Wang Y., Zhang S., Zhan Y. et al., Carbohydr. Polym., 2017, Vol. 166, pp. 219227. DOI: 10.1016/j.carbpol.2017.02.107.

54. Schramm L., Emulsion, foams and suspensions: fundamentals and applications, Wiley, 2005, $448 \mathrm{p}$.

55. Tinoko I., Zauer K., Veng Dzh., Paglisi Dzh. Fizicheskaya khimiya. Printsipy i primenenie $\mathrm{V}$ biologicheskikh naukakh, M., Tekhnosfera, 2005, $744 \mathrm{p}$.

56. Quirino J.P., Terabe S., J. Chromatogr A., 2000, Vol. 902, pp. 119-135.

57. Arnett S.D., Lunte C.E., Electrophoresis, 2003, Vol. 24, pp. 1745-1752.

58. Quirino J. P., Terabe S., Anal. Chem., 2000, Vol .72, pp. 1023-1030.

59. Moris P. Poverkhnost' i mezhfaznye granitsy $\mathrm{v}$ okruzhayushchei srede ot nanourovnya k global'nomu masshtabu. M., Binom. Lab. znanii, 2013, $540 \mathrm{p}$.

60. Leung S.-A., de Mello A.J., J. Chromatogr A., 2002, Vol. 979, pp. 171-170.

61. Duan J., Hy B., He M., Electrophoresis, 2012, Vol. 33, pp. 2953-2960.

62. Arnett S.D., Lunte C.E., Electrophoresis, 2007, Vol. 28, pp. 3786-3793.

63. Kamentsev M. Ya., Kamentsev Ya.S., Moskvin L.N., Yakimova N.M., J. Anal. Chem., 
2011, Vol. 66, pp. 212.

65. Aranas A.T., Guidote A.M., Quirino J.P.,

64. Huang H., Chen Z., Yan X., J. Sep. Sci., Anal. Bioanal. Chem., 2009, Vol. 394, pp. 1752012, Vol. 35, pp. 436-444.

185.

Кущев Петр Олегович - доцент кафедры высокомолекулярных соединений и коллоидной химии, к.Х.н., Воронежский государственный

Kushchev Petr O. - Ph.D. (chemistry), associate университет, Воронеж

prof., department of polymer science and colloid chemistry, Voronezh State University, Voronezh 